ACTA AGROBOTANICA

Vol. 62 (1): 147-153

2009

\title{
GROWTH AND YIELD OF CUCUMBER UNDER NO-TILLAGE CULTIVATION USING RYE AS A COVER CROP
}

\author{
Małgorzata Jelonkiewicz, Andrzej Borowy
}

\begin{abstract}
Department of Vegetable Crops and Medicinal Plants, University of Life Sciences, 20-068 Lublin, St. Leszczyńskiego 58, Poland e-mail: andrzej.borowy@up.lublin.pl
\end{abstract}

Received: 17.02.2009

\section{Abstract}

In the first two years of study, method of cultivation did not affect the emergence of cucumber seedlings. In the third year, a drought occurring during the spring was the cause of poor seedling emergence on no-tilled plots. Six weeks after seed sowing, the shoots of cucumbers grown on the no-tilled plots were much shorter, especially in the last study year. At the time of cucumber seed sowing, no-tilled soil contained less phosphorus and potassium and in the middle of the fructification period the content of these elements in cucumber leaves was higher under no-tillage cultivation. Additional spring fertilization of rye with ammonium nitrate resulted in a higher $\mathrm{N}-\mathrm{NO}_{3}$ content in soil and later in a higher nitrogen content of cucumber leaves. The content of calcium and magnesium in soil and than in cucumber leaves was independent of the cultivation method. In the first two years, method of cultivation did not affect the yield of cucumber fruits and in the third year the yield was much lower under no-tillage because of poor seedling emergence. Moreover, in the third year the fruits were smaller and dry matter content of the fruit was significantly higer under no-tillage cultivation.

Key words: direct drilling, seedling emergence, dry matter, mineral elements

\section{INTRODUCTION}

No-tillage cultivation with cover crops is the most effective technique for halting soil erosion and making food production truly sustainable. Other advantages are as follows: reduction of fuel consumption and nitrate leaching, preservation of soil structure, earthworms and other soil fauna, improved aeration and internal drainage (B aker et al. 1996; Ho ff man and Regnier, 2006; S a inju and Singh, 1997; W y l a nd et al. 1996; Z a nd stra et al. 1998). Moreover, cover crops can be useful in the control of weeds, plant diseases and insects (B o r ow y, 2004; M a si u n as, 1998, T e a s d a le et al. 2004). No-till- age and cover crops have an effect on soil temperature, humidity and other physical properties (B o r o w y et al. 2000) and therefore they can also influence the uptake of nutrients by cultivated plants (B orow y and Jelonkiewicz, 2000; Knavel and Herron, 1981; Knavel et al. 1977; Mullin s et. al. 1980; Now osielski, 1988). Cover crop residues with a high carbon-to-nitrogen ratio (e. g. rye) can immobilize soil nitrogen, reducing yields ( $\mathrm{S} \mathrm{h}$ o $\mathrm{n} \mathrm{b} \mathrm{e} \mathrm{ck}$ et al. 1993; Z a n d stra et al. 1998).

In dependence on environmental circumstances, cultivated plants differ in their reaction to no-tillage (B a k e r et al. 1996). In Poland, cucumber is one of the most important vegetable species (K n a flew s$\mathrm{k} \mathrm{i}, 2007)$ and rye is a valuable winter hard cover crop adapted well to the country's natural conditions ( $\mathrm{J} \mathrm{e}$ lonkiewicz and B orowy, 2005). In an experiment carried out by B e s te (1973) in the northeastern United States, cucumbers sown directly into a killed rye mulch produced yield lower than in conventional tillage. In studies of $\mathrm{Z}$ and s tra et al. (1998), rye as a cover crop provided protection from wind erosion but caused some cucumber yield reduction under adverse growing conditions. The aim of this experiment was to study the effect of no-tillage and rye as a cover crop on growth and yield of cucumbers cultivated in southeastern Poland and also on content of several components in cucumber leaves and fruits.

\section{MATERIALS AND METHODS}

The studies were conducted in the Felin Experimental Farm on loess-like soil containing 1.6\% of organic matter and with a $\mathrm{pH}$ of 6.5. The experiment was repeated three times in the years 1997-1998, 1998-1999 and 1999-2000. Half of the experimental field was ploughed $20 \mathrm{~cm}$ deep, fertilized with $22 \mathrm{~kg}$ 
$\mathrm{P} \times \mathrm{ha}^{-1}$ super - phosphate and $50 \mathrm{~kg} \mathrm{~K} \times \mathrm{ha}^{-1}$ potassium salt and then tilled with a rotary cultivator at the beginning of September. Three weeks later rye (Secale cereale $\mathrm{L}$.) was sown at $140 \mathrm{~kg} \times \mathrm{ha}^{-1}$ by hand and then harrowed $3 \mathrm{~cm}$ deep. The other half of field was fertilized with the same quantities of superphosphate and potassium salt and ploughed $20 \mathrm{~cm}$ deep in November. In March of the following year, rye was top dressed with ammonium nitrate $50 \mathrm{~kg} \mathrm{~N} \times \mathrm{ha}^{-1}$ and on May 7-8 it was sprayed with glyphosate (N-phosphonometyl) glicyne) at $1440 \mathrm{~g}$ ai $\times \mathrm{ha}^{-1}$ plus adjuvant. At that time, rye was $70-90 \mathrm{~cm}$ tall and at the pre-anthesis stage of growth. Ten days later the desiccated rye was rolled flat and left on the soil surface. Then the samples were taken from the $1-20 \mathrm{~cm}$ soil layer with the aim to determine the content of mineral elements (Tab. 1).

Table 1

Content of mineral elements in the 1-20 $\mathrm{cm}$ soil layer $\left(\mathrm{mg} \times \mathrm{dcm}^{-3}\right)$ in the middle of May in 1998-2000.

\begin{tabular}{|c|c|c|c|c|c|c|c|c|c|c|c|c|c|c|c|}
\hline \multirow{2}{*}{$\begin{array}{l}\text { Method of } \\
\text { cultivation }\end{array}$} & \multicolumn{3}{|c|}{ Nitrogen $-\mathrm{NO}_{3}$} & \multicolumn{3}{|c|}{ Phosphorus } & \multicolumn{3}{|c|}{ Potassium } & \multicolumn{3}{|c|}{ Calcium } & \multicolumn{3}{|c|}{ Magnesium } \\
\hline & $\stackrel{\infty}{\sigma}$ & ลे & ষ্ণ & $\stackrel{\infty}{2}$ & ลे & 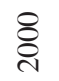 & $\stackrel{\infty}{\sigma}$ & ڤे & ه্ণ & $\stackrel{\infty}{2}$ & ळे & ه্ণ & $\stackrel{\infty}{\sigma}$ & ڤे & ষ্ণ \\
\hline Conventional & 61 & 66 & 69 & 122 & 55 & 50 & 261 & 120 & 110 & 710 & 435 & 460 & 85 & 57 & 52 \\
\hline No-tillage & 74 & 49 & 58 & 95 & 50 & 48 & 190 & 102 & 75 & 585 & 495 & 480 & 62 & 61 & 56 \\
\hline
\end{tabular}

Between May 17 and May 19, cucumbers $(\mathrm{Cu}$ cumis sativus $\mathrm{L}$.) 'Aladyn $\mathrm{F}_{1}$ ' were sown on the half of the field covered with rye mulch and also on the second half of the field, tilled conventionally $15 \mathrm{~cm}$ deep with a rotary cultivator. The seeds were sown by hand in four $2 \mathrm{~cm}$ deep and $6 \mathrm{~m}$ long lines with inter-row spacing of $1.5 \mathrm{~m}$. The seeding rate was $2.0 \mathrm{~kg} \times \mathrm{ha}^{-1}$. One line was considered as one replicate of $9.0 \mathrm{~m}^{2}$ area. Top dressing with nitrogen at $50 \mathrm{~kg} \mathrm{~N} \times \mathrm{ha}^{-}$ ${ }^{1}$ (calcium nitrate) was effected 5 and 9 weeks after seeding. Emerged seedlings were counted 3 weeks after seeding and then 3 weeks later the shoot length of all plants was measured. Harvesting of fruits was carried out every 3-4 days. At harvest, total and marketable yields as well as weight, length and diameter of 20 marketable fruits were measured. In the middle of the cucumber's fructification (beginning of August), samples of young, fully developed leaves were collected, dried and then the content of total nitrogen (distillation method), phosphorus (colorimetric method), potassium (flame photometry), calcium (flame photometry) and magnesium (atomic absorption spectrometry) in the leaves was determined. At the same time, the content of dry matter in cucumber fruits (oven dry method) was also measured. The plots were weeded twice: 3 and 7 weeks after seeding and weed infestation was described in a separate paper ( $\mathrm{J} \mathrm{e} \mathrm{lonkiewicz} \mathrm{and}$ B o r o w y, 2005). The obtained results were studied by analysis of variance and the significance of differences was determined using Tukey's test at 0.05 probability level.

\section{RESULTS AND DISCUSSION}

Method of cultivation did not affect the emergence of cucumber seedlings in 1998 and 1999, but it had a negative influence in the last year of study (Tab. 2). In May 2000, air temperatures were much higher than usual, with almost no precipitation. Moreover, on the no-tilled plots the rye plants depleted the soil of the rest of water. In these conditions, the seeding and then the seedling emergence were much more difficult than under conventional tillage. Similarly, Li e b 1 et al. (1992) observed soil water depletion caused by rye killed at soybean planting during dry periods.

Six weeks after seed sowing, the length of cucumber shoots grown on the no-tilled plots was only about half of that under conventional cultivation. It was also dependent on the year and on the interaction between years and method of cultivation. The shortest shoots were developed by plants grown on the no-tilled plots in the dry year 2000 (Tab. 2). In Poland in the spring, the temperature of no-tilled soil covered with rye mulch can be up to $5^{\circ} \mathrm{C}$ lower than under conventional cultivation (B o r o w y et al. 2000) and cucumber is a warm weather vegetable with roots sensitive to cold (P u d e l s k i, 1993).

Rye, as a high carbon-to-nitrogen ratio cover crop, was fertilized additionally with ammonium nitrate at the beginning of spring and this resulted in a higher content of nitrogen $\mathrm{N}-\mathrm{NO}_{3}$ in the soil during the seeding of cucumber seeds (Tab. 1) and then a higher nitrogen content in cucumber leaves in the middle of the fructification period (Tab. 3). The rye 
Table 2

Seedling emergence and length of cucumber shoot in dependence on method of cultivation in 1998-2000.

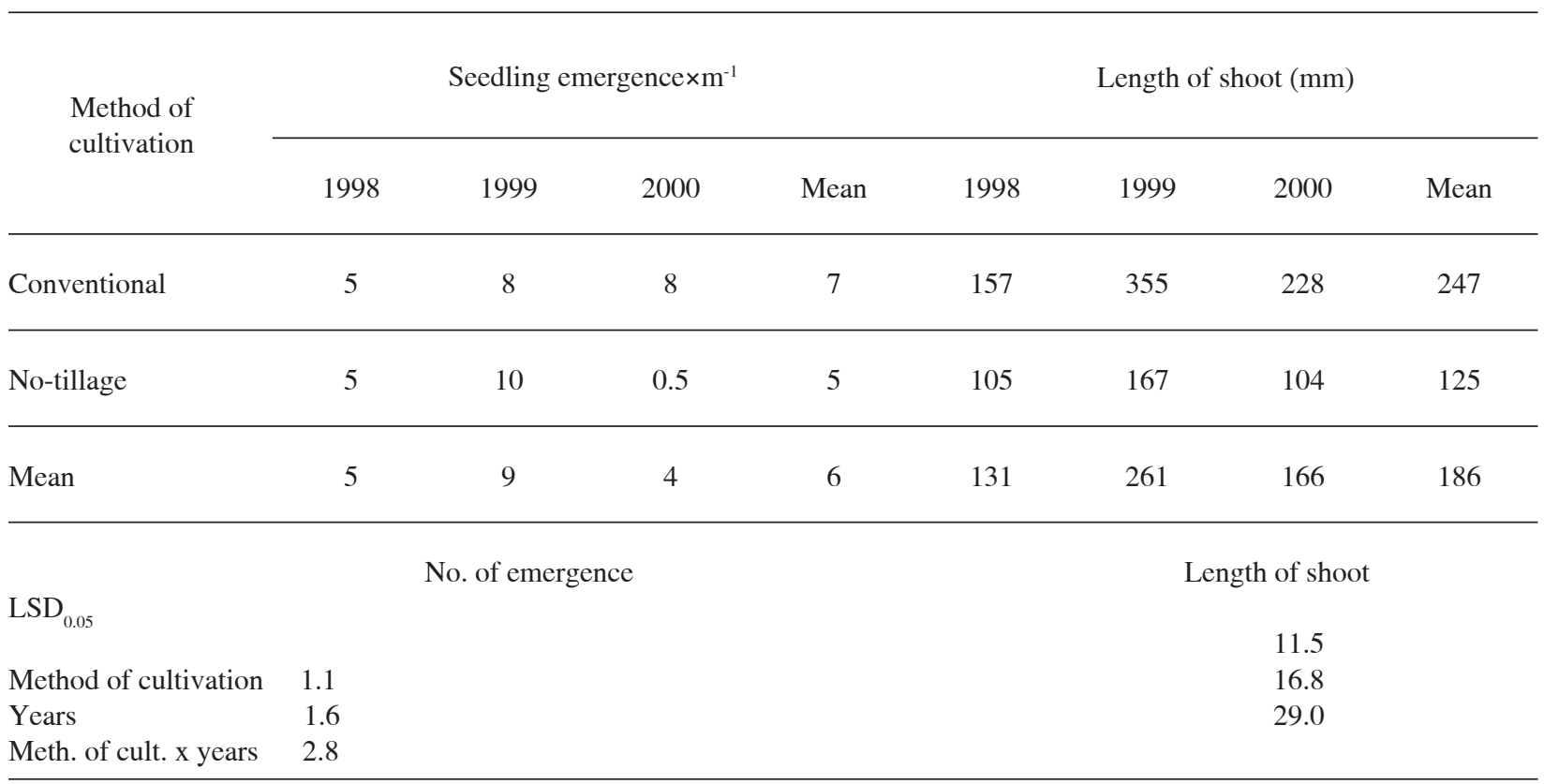

Table 3

Content of nitrogen, phosphorus, potassium, calcium and magnesium in cucumber leaves (\% of dry matter) in dependence on method of cultivation in 1998-2000.

\begin{tabular}{|c|c|c|c|c|c|c|c|c|c|c|c|c|}
\hline \multirow{2}{*}{$\begin{array}{l}\text { Method of } \\
\text { cultivation }\end{array}$} & \multicolumn{4}{|c|}{ Nitrogen } & \multicolumn{4}{|c|}{ Phosphorus } & \multicolumn{4}{|c|}{ Potassium } \\
\hline & 1998 & 1999 & 2000 & Mean & 1998 & 1999 & 2000 & Mean & 1998 & 1999 & 2000 & Mean \\
\hline Conventional & 2.12 & 2.08 & 2.91 & 2.37 & 0.53 & 0.42 & 0.65 & 0.53 & 2.66 & 2.20 & 3.16 & 2.67 \\
\hline No-tillage & 2.06 & 2.58 & 3.52 & 2.72 & 0.55 & 0.50 & 0.73 & 0.59 & 2.99 & 2.78 & 3.30 & 3.02 \\
\hline Mean & 2.09 & 2.33 & 3.22 & 2.55 & 0.54 & 0.46 & 0.69 & 0.56 & 2.83 & 2.49 & 3.23 & 2.85 \\
\hline \\
\hline \multicolumn{3}{|l|}{ Years } & & 0.118 & & & & 0.037 & & & & 0.083 \\
\hline \multicolumn{3}{|c|}{ Meth. of cult. $\mathrm{x}$ years } & & 0.217 & & & & n.s. & & & & 0.153 \\
\hline
\end{tabular}

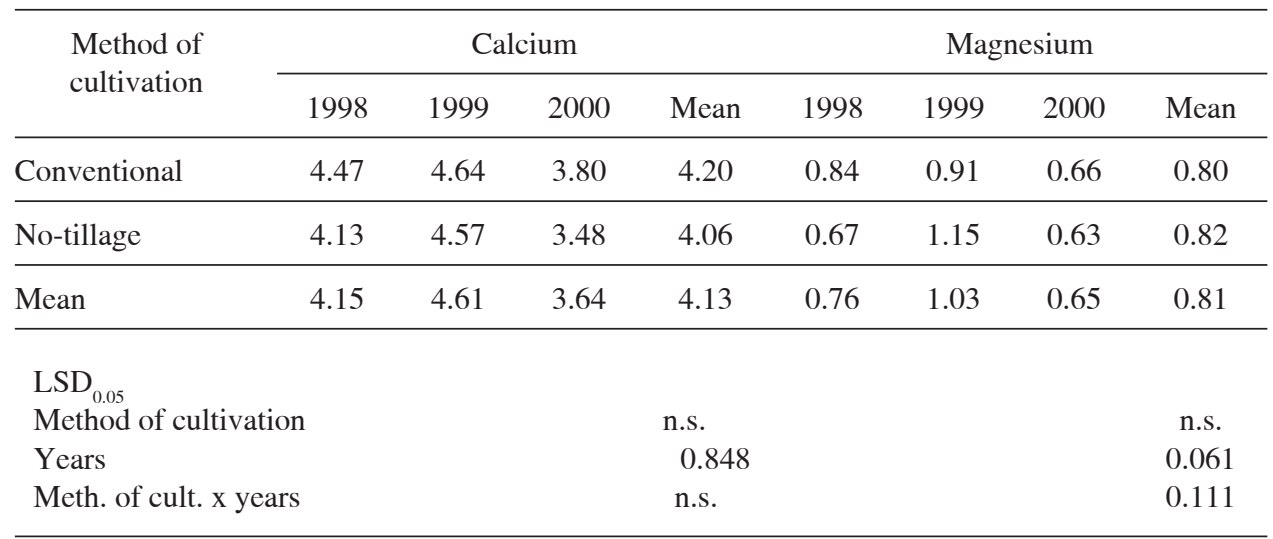




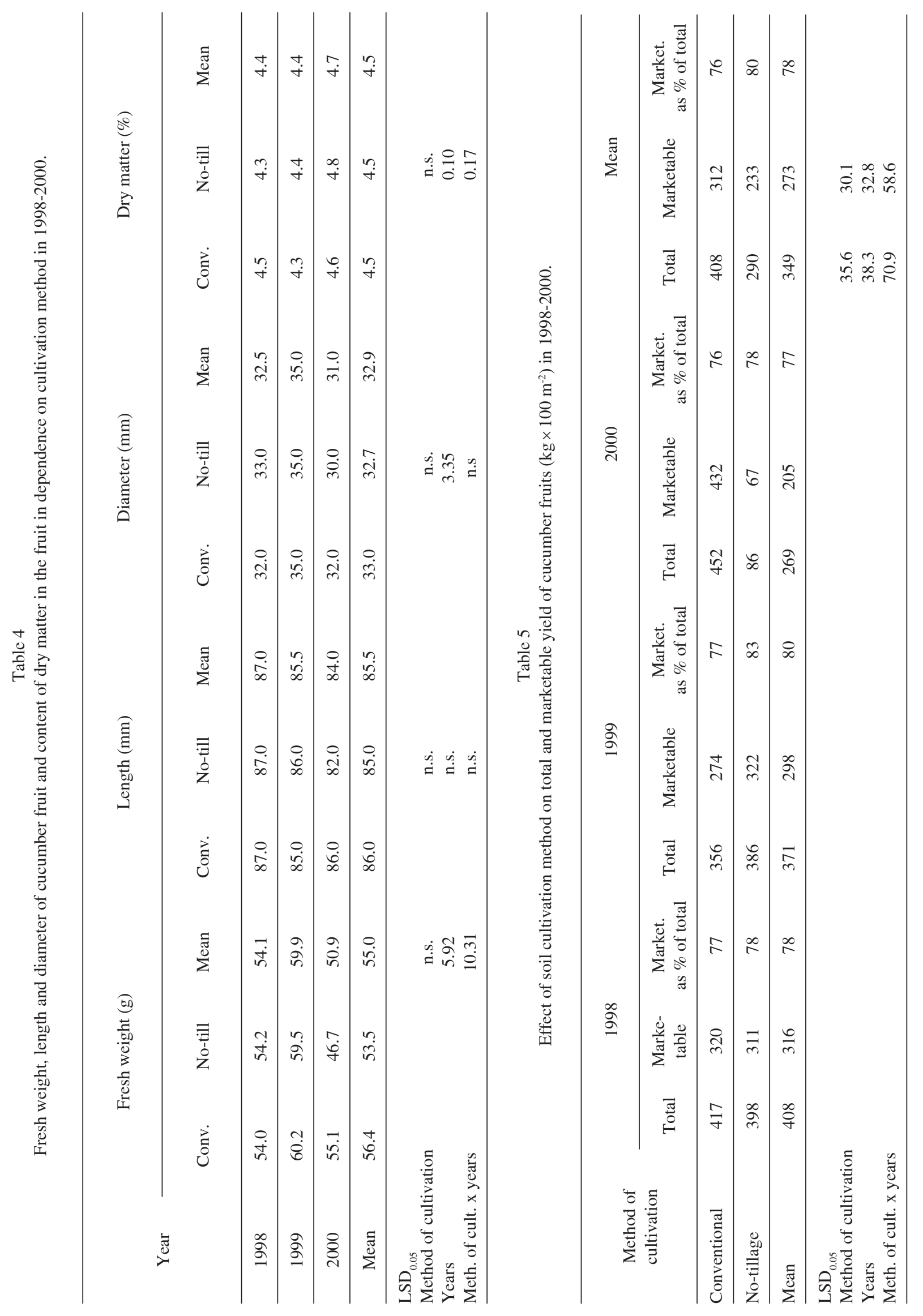



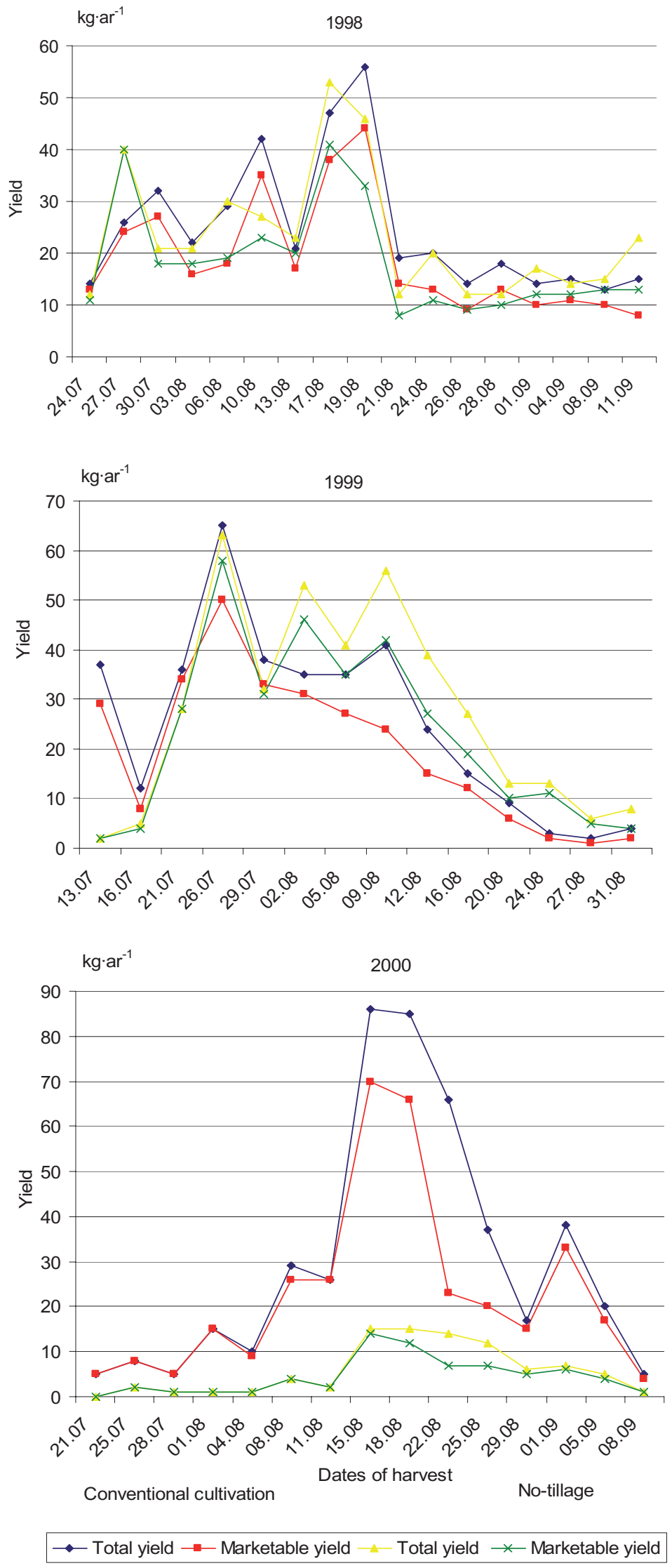

Fig. 1. The pattern of cucumber fruits harvesting under conventional tillage and no-tillage with rye as a cover crop in 1998-2000. 
plants absorbed a part of phosphorus and potassium from the soil and therefore their content was lower on the no-tilled plots (Tab. 1). In the middle of August, the majority of rye mulch was already decomposed (B o r ow y and J e lonki ew i c z, 2005) and served as a kind of organic fertilization. This could be at least a partial explanation for the higher content of phosphorus and potassium in cucumber leaves under no-tillage cultivation at this time (Tab. 3). The content of calcium and magnesium in the soil and then in cucumber leaves was independent of the cultivation method. The content of all the studied mineral elements in cucumber leaves was at a satisfactory level (N o w o s i e ls ki, 1988) and depended mainly on the year of study. There was also a significant interaction between the content of nitrogen, potassium and magnesium and the year of study (Tab. 3). In an experiment conducted by $\mathrm{K} n$ a vel et al. (1977), the nitrogen content of cucumber leaves was lower at one and higher at six sampling dates under no-tillage cultivation with bluegrass or winter wheat as a cover crop.

Fruit harvesting started in the second or the third decade of July and was completed till the end of August - middle of September. In 1999 there was a tendency for slower fruit growing under no-tillage cultivation and in 2000 first fruit harvesting on the no-tilled plots was carried out 4 days later than on the conventionally tilled plots (Fig. 1). This tendency was also observed in notillage cultivation of other warm weather vegetables: snap beans and tomatoes (B or o w y and J e l o n k i e w i c z, 2000; B o row y and Komos a, 2003).

Method of cultivation did not affect fresh weight, length, diameter or dry matter content of cucumber fruits. Only in the year 2000, the fruits were smaller and dry matter content of the fruit was significantly higher under no-tillage cultivation (Tab. 4).

Method of cultivation did not affect the yield of cucumber fruits in 1998 and 1999. However, in the last year of study, the yield harvested on the no-tilled plots was much lower because of poor seed emergence in this treatment. This agrees with the statement of $\mathrm{Z}$ a n d s tra et al. (1998) that under adverse growing conditions the yield of cucumber fruits harvested in no-tillage with rye as a cover crop can be lower than in conventional cultivation. The share of marketable yield in total yield ranged from $76 \%$ to $83 \%$ and was independent of the cultivation method (Tab. 5).

\section{CONCLUSIONS}

1. Spring drought caused poor emergence of cucumber seedlings under no-tillage cultivation with rye as a cover crop.
2. The initial growth of cucumber plants was slower on the no-tilled plots covered with rye mulch.

3. The content of calcium and magnesium in soil at the beginning of cultivation and in cucumber leaves in the middle of the fructification period was independent of, and the content of nitrogen, phosphorus and potassium was dependent on the cultivation method.

4. Under normal weather conditions, method of cultivation did not affect the yield or weight, length, diameter and dry matter content of cucumber fruits. Under dry weather, the yield of cucumber fruits harvested on the no-tilled plots was lower, the fruits were smaller and the dry matter content of fruit was higher.

5. The share of marketable yield was independent of the cultivation method.

\section{REFERENCES}

B a k e r C. J., S a x t o n K. E., R i t c h i e W. R., 1996. No-tillage seeding. Science and Practice. CAB International, University Press, Cambridge: 258.

B e s t e C. E. 1973. Evaluation of herbicides in no-till planted cucumbers, tomatoes, and lima beans. Proc. Northeast. Weed Sci. Soc. 27: 231-239.

B o r o w y A. 2004. Effect of no-tillage and rye mulch on occurrence of weeds and aphids and on yield of cabbage, carrot and red beet. Acta Hort. 638: 147-150.

B o r o w y A., Komosa A., 2003. Growth and yield of tomatoes under no-tillage cultivation using rye as cover crop and tripple top-dressing. Folia Hort. Suppl. 1: 425-427.

B o r ow y A., Kon op iński M., J e 1 on ki e w i c z M., 2000. Effect of no-tillage and rye mulch on soil properties, weed infestation and yield of carrot and red beet. Proc. XI ${ }^{\mathrm{eme}}$ Colloque International Sur La Biologie Des Mauvaises Herbes, Dijon: 339-345.

B o r o w y A., J e l o n ki e w i c z M., 2000. Weed Infestation, Growth, Yield and Content of Macroelements in Snap Bean Plants Under No-tillage Cultivation Using Rye as Cover Crop. Ann. UMCS, Sect. EEE, VIII, Suppl.: 261-268.

H o f f m a n M. L., R e g n i e r E. E., 2006. Contributions to Weed Suppresion from Cover Crops. In: Singh H. P., Batish D. R., Kohli R. K. (Eds.), Handbook of Sustainable Weed Management. Haworth Press, New York: 51-75.

J e 1 o n k i e w i c z M., B or ow y A., 2005. Effect of rye mulch on growth of weeds under no-tillage cultivation. Allelopathy J. 16 (1): 113-122.

K n a f l e w s k i M., 2007. Production of vegetables in Poland, in Europe and in the world. Produkcja warzyw w Polsce, w Europie i na świecie. In: Knaflewski M. (Ed.), Ogólna uprawa warzyw. PWRiL, Poznań: 14-17 (in Polish). 
Knavel D. E., E1li s J., Morris on J., 1977. The Effects of Tillage Systems on the Performance and Elemental Absorbtion by Selected Vegetable Crops. J. Amer. Soc. Hort. Sci. 102 (3): 323-327.

K n a v e 1 D. E., Herron J. W., 1981. Influence of Tillage System, Plant Spacing, and Nitrogen on Head Weight, Yield, and Nutrient Concentration of Spring Cabbage. J. Amer. Soc. Hort. Sci. 106 (5): 540-545.

Li e b 1 R., S i m m o n s F. W., W a x L. M., S t o 11 e r E. W., 1992. Effect of Rye (Secale cereale) Mulch on Weed Control and Soil Moisture in Soybean (Glycine max). Weed Technology, 6 (4): 838-846.

M a s i u n a s. B., 1998. Production of vegetables using cover crop and living mulches - a reviev. J. Veg. Crop. Prod., 4 (1): 11-31.

Mullins C. A., Tompkins F. D., P arks W. L., 1980. Effects of Tillage Methods on Soil Nutrient Distribution, Plant Nutrient Absorbtion, Stand, and Yields of Snap Beans and Lima Beans. J. Amer. Soc. Hort. Sci. 105 (4): 591-593.

N o w o s i e 1s k i O. 1988. Zasady opracowywania zaleceń nawozowych w ogrodnictwie. PWRiL, Warszawa: 310.

P u d e l s k i T. 1993. Cucumber - Cucumis sativus L. Ogórek. In: Pudelski T. (Ed.), Uprawa warzyw pod osłonami. PWRiL, Warszawa: 173-207.

S a i n j u U. M., S i n g h B . P., 1997. Winter cover crops for sustainable agricultural systems: Influence on soil properties, water quality, and crop yields. HortScience, 32: 21-28.

S chonbeck M., Herbert S., De Gregorio R., Mangan F., Guillard K., Sideman E., Herbst J., J a y e R., 1993. Cover Cropping Systems for Brassicas in the Northeastern United States: 1. Cover Crop and Vegetable Yields, Nutrients and Soil Conditions. J. Sustainable Agric. 3 (3/4): 105-132.

T e a s d a le J. R., Abdu 1-B aki A. A., Mills D. J., Thorpe K. W., 2004. Enhanced Pest Management with Cover Crop Mulches. Acta Hort. 638: 135-140.
W y $\mathrm{l}$ a n d L. J., J a c k s o n L. E., Ch a ne y W. E., K lonsky K., Koike S. T., K i m ple B., 1996. Winter cover crops in a vegetable cropping system: Impacts on nitrate leaching, soil water, crop yield, pests and management costs. Agriculture, Ecosystems and Environment, 59: 1-17.

Z a nd st r a B. H., C h a se W. R., M a s a b n i J. G., 1998. Interplanted Small Grain Cover Crops in Pickling Cucumbers. Hort Technology, 8 (3): 356-360.

\section{Wzrost i plonowanie ogórka w uprawie bezorkowej z użyciem żyta jako rośliny okrywowej}

\section{Streszczenie}

Podczas pierwszych dwóch lat badań metoda uprawy nie miała wpływu na wschody ogórka, natomiast w trzecim roku wiosenna susza była przyczyną słabych wschodów w uprawie bezorkowej. Po upływie sześciu tygodni od siewu nasion pędy roślin ogórka rosnących na poletkach uprawianych metodą bezorkową były dużo krótsze, zwłaszcza w ostatnim roku badań. Skutkiem dodatkowego wiosennego nawożenia żyta saletrą amonową była większa zawartość $\mathrm{N}-\mathrm{NO}_{3}$ w glebie a także większa zawartość azotu w liściach ogórka. Podczas siewu nasion ogórka gleba pochodząca z poletek uprawianych metodą bezorkową zawierała mniej fosforu i potasu, natomiast liście ogórka zebrane $\mathrm{z}$ roślin rosnących na poletkach tej kombinacji i będących w pełni owocowania zawierały więcej tych pierwiastków. Zawartość magnezu i wapnia w glebie i w liściach ogórka była niezależna od metody uprawy. Podczas pierwszych dwóch lat badań metoda uprawy nie miała wpływu na plonowanie ogórka, natomiast w trzecim roku dużo mniejszy plon uzyskano w uprawie bezorkowej, czego powodem były słabe wschody $\mathrm{w}$ tej kombinacji. Ponadto $\mathrm{w}$ tym roku owoce zebrane z roślin uprawianych metodą bezorkową były mniejsze i zawierały więcej suchej masy. 